\title{
Trestné činy súvisiace
}

s verejným obstarávaním*

\section{Related Criminal Offenses to Public Procurement}

\author{
Andrej Beleš**
}

\begin{abstract}
Abstrakt
Autor sa $v$ stúdii zameriava na komparáciu slovenskej a reskej právnej úpravy trestných činov súvisiacich $s$ verejným obstarávanim. Komparácia pozostáva z. bližšej analýzy trestného činu machinácii pri verejnom obstarávani a verejnej dražbe podla \266 až 268 slovenskébo Trestnébo zákona a trestných činov zjednání

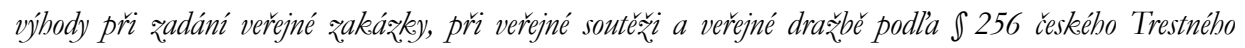
zákonnike a pletich pri zadáni verejné zakázky a pri veřejné soutěži podla \ 257 českého Trestného zákonnika. $V$ komparácii je zohl'adnená aj rozhodovacia činnost' vnútroštátnych súdov, resp. Súdneho dvora EÚ.
\end{abstract}

\section{Klíčová slova}

Machinácie; pletichy; verejné obstarávanie; zadání veréjné zákazky; trestný čin.

\begin{abstract}
The author focuses on the comparison of Slovak and Czech legal regulation of criminal offenses related to public procurement. The comparison consists of a closer analysis of the crime of machinations in public procurement and public auction according to Sections 266 to 268 of the Slovak Criminal Code and criminal offenses of obtaining an advantage in awarding a public contract, public tender and public auction according to Section 256 of the Czech Criminal Code and machinations in public procurement and a public tender pursuant to Section 257 of the Czech Criminal Code. The comparison also takes into account the decisionmaking activity of national courts, resp. Court of Justice of the EU.
\end{abstract}

\section{Keywords}

Machinations; Public Procurement; Award of Public Contract; Criminal Offense.

\section{Úvod}

Trestné činy súvisiace s verejným obstarávaním sú mimoriadne závažným druhom ekonomickej kriminality a zároveň často súčast’ou organizovaného zločinu. Organizovaný zločin sa tradične zameriava na obchodovanie s komoditami, s ktorými nakladanie je právne reprobované, čiže ide o nezákonné uspokojovanie dopytu na trhu - typicky obchodovanie s určitými druhmi zbraní, obchodovanie s l’ud'mi, s l'udskými orgánmi s omamnými a psychotropnými látkami a pod.

\footnotetext{
* Príspevok spracovaný v rámci projektu APVV č. APVV-17-0641: „Zefektívnenie právnej úpravy verejného obstarávania a jej aplikácie v kontexte práva Európskej únie“.

** JUDr. Andrej Beleš, PhD., odborný asistent, Ústav európskeho práva, Právnická fakulta, Univerzita Komenského v Bratislave / Assistant Professor, Institute of European Law, Faculty of Law, Comenius University in Bratislava, Slovak Republic / E-mail: andrej.beles@flaw.uniba.sk / ORCID: 0000-0001-8418-0106
} 
Súčast'ou organizovaného zločinu sú však aj aktivity, ktoré sa nezameriavajú na substitúciu trhu, ale ich jediným ciel’om je protiprávne odčerpávat' prostriedky z verejných zdrojov. Formy týchto aktivít sa menia v závislosti od ekonomického a hospodárskeho štádia vývoja spoločnosti, v minulosti išlo najmä o tzv. privatizačnú trestnú činnost' a tzv. tunelovanie privatizovaných obchodných spoločností. ${ }^{1} \mathrm{~V}$ súčasnosti sú takými rozšírenými aktivitami daňové trestné činy, predovšetkým daňové podvody, ktorých podstatou je neoprávnené uplatňovanie nároku na vrátenie dane z pridanej hodnoty alebo spotrebnej dane ( $\int 277$ a TZ²), podvody a korupcia spojená s tzv. eurofondami, teda poškodzovanie finančných záujmov Európskej únie a súvisiace trestné činy ( $\int 261$ až 263 TZ), ako aj machinácie pri verejnom obstarávaní a verejnej dražbe (\$S 266 až 268 TZ). ${ }^{3}$

Tieto trestné činy sa v súlade s paradigmou zvyšovania sofistikovanosti ekonomickej kriminality náročne objasňujú vzhladom na zapojenie typicky mimotrestných právnych inštitútov, najmä civilnoprávnych, obchodnoprávnych a administratívnoprávnych do skutkových zistení orgánov činných v trestnom konaní. Podstatou trestnoprávne relevantného konania je totiž najmä porušenie týchto mimotrestných právnych noriem, čiže ide o „podvod“ voči zákonne ustanovenému režimu. Tento fakt vystihuje aj samotný pojem machinácie, česky pletichy, ktorý pomenováva podvodné, úskočné konanie. ${ }^{4}$

Problém machinácií pri verejnom obstarávaní z kriminologicko-ekonomického hladiska vyvstáva z faktu, že štát prostredníctvom svojich orgánov verejnej moci často nekoná ako „dobrý hospodár“. Na správu súkromného vlastníctva sú vynakladané intelektuálne schopnosti a individuálne snaženie vlastníka, aby bol dosiahnutý maximálny zisk pri minimálnych nákladoch, alebo aspoň aby hodnota majetku bola zachovaná. Pri verejnom vlastníctve je pluralita zdrojov intelektuálnych schopností a individuálneho snaženia jednotlivých súkromných vlastníkov nahradená „správcom“ verejného majetku, ktorý nie vždy spravuje verejný majetok riadne, a to z rôznych dôvodov - pre neschopnost' obsiahnut' viac než len potreby úzkeho okruhu l’udí ${ }^{5}$, príp. s motívom získat'

1 ŠANTA, Ján. Machinácie pri verejnom obstarávani podla Trestnébo zákona Slovenskej republikey. Dostupné na: https://www.ja-sr.sk/files/Machinacie_JUDr_Santa.pdf [cit. 1. 12. 2020].

2 Zákon č. 300/2005 Z. z. Trestný zákon v znení neskorších predpisov. Na zákon je v texte odkazované skratkou TZ alebo slovenský TZ.

3 K ekonomickej kriminalite: STRÉMY, Tomáš. Vymedzenie pojmu ekonomická kriminalita. Justičná revue, 2010, roč. 62, č. 3, s. 378-385; Ďalej tiež STRÉMY, Tomáš. Nové trendy v ekonomickej kriminalite. In: Páchatel' hospodárskej kriminality v Slovenskej republike. Trnava: Právnická fakulta Trnavskej univerzity, 2009, s. 24-37.

4 Etymologicky je potrebné sa zamerat' na latinské machinatio, machinatus, čo znamená strojit', chystat', vymýšl'at', odvodené od latinského machina - stroj, valec, obliehací stroj, l’stivý výmysel, úskok. KRÁLIK, Lubor. Stručný etymologický slovník slovenčiny. Bratislava: Veda, vydavatel'stvo SAV, 2015, s. 339.

5 Problém kolektivizmu a kolektívneho spravovania majetku vystihol Hayek: „Vel’mi dôležitý je qákladný fakt, že žiadny človek nemôže ziskat' preblad o tom, co presabuje isté obmedzené pole, uvedomovat' si naliehavost' potrieb, ktorých počet by prekročil istú obmedzenú veličinu. Či sa užjeho záujmy sústred’ujú okolo jeho vlastných fyzických potrieb, alebo či sa úprimne zaujima blahobyt každej l’udskej bytosti, ktorú pozná, ciele ktorými sa môže zaoberat’ budú tvorit’ vždy len nekonečne malý zlomok potrieb všetkéch l'udí. "HAYEK, Fridrich August. Cesta do nevolnictva. Bratislava: Nadácia F. A. Hayeka, 2012, s. 71. 
vlastný majetkový prospech. Obohacovanie úradníkov z verejných zdrojov je imanentnou súčast'ou fungovania orgánov verejnej moci, s čím sa dlhodobo snaží právny poriadok vyrovnat'. ${ }^{6}$ Zo súčasného pohl'adu to môže okrem trestného činu machinácií pri verejnom obstarávaní a verejnej dražbe viest’ $\mathrm{k}$ spáchaniu trestného činu porušovania povinností pri správe cudzieho majetku alebo trestných činov korupcie.

\section{Machinácie pri verejnom obstarávaní v slovenskej a českej právnej úprave}

Porušovanie právnych predpisov súvisiacich s verejným obstarávaním, ktoré dosahuje trestnoprávnu relevanciu, je $\mathrm{v}$ slovenskom právnom poriadku postihované trestným činom machinácií pri verejnom obstarávaní a verejnej dražbe podl’a \ 266 až 268 slovenského TZ. V českom právnom poriadku - v zmysle českého $\mathrm{TZ}^{7}$ - je toto protiprávne konanie trestnoprávne riešené dvomi trestnými činmi: zjednání výhody prí zadáni veřejné zakázky, pri verejné soutěži a veřejné dražbě podl'a \256 českého TZ, resp. pletichy prí zadání verejné zakázky a pri veřejné soutěži $i$ podl'a \ 257 českého TZ. ${ }^{8}$

Trestný čin machinácií pri verejnom obstarávaní a verejnej dražbe pozostáva z troch základných skutkových podstát:

1. prvá z nich (\$ 266 slovenského TZ):

a) postihuje konanie $\mathbf{v}$ rozpore so všeobecne záväzným právnym predpisom o verejnom obstarávaní alebo verejnej dražbe (prvá alinea objektívnej stránky), pričom týmito predpismi sú zákon o verejnom obstarávaní ${ }^{9}$ a zákon o dobrovol’ných dražbách ${ }^{10}$,

b) postihuje dojednanie prednosti alebo výhodnejších podmienok niektorému sút’ažitel’ovi alebo účastníkovi verejnej dražby na úkor iných sút'ažitel'ov alebo účastníkov verejnej dražby (druhá alinea objektívnej stránky), pričom v oboch prípadoch musí byt' daná súvislost’ s verejným obstarávaním a verejnou dražbou;

6 GREGOR, Martin. Rímski magistráti a trestné činy proti verejnému majetku. In SALÁK, Pavel jr. a Lucie MRÁZKOVÁ. Ius Honorarium-římské magistratury a jejich činnost: sborník z konference. 1. vyd. Brno: Masarykova univerzita, 2019, s. 21-43.

7 Zákon č. 40/2009 Sb. Trestní zákonník v znení neskorších predpisov. Na zákon je v texte odkazované skratkou český TZ.

8 V d’alšom ustanovení český TZ kriminalizuje pletichy při veřejné dražbě (\$ 258 českého TZ), čo sa ako trestnoprávne relevantné konanie z pohl'adu slovenského TZ subsumuje pod trestný čin machinácií pri verejnom obstarávaní a verejnej dražbe podl'a \ 266 a nasl. slovenského TZ. Ked’že je však tento príspevok zameraný na problematiku verejného obstarávania / veřejných zakáąek, nebudeme sa trestnému činu pletichy pri verejné dražbě bližšie venovat'.

9 Zákon č. 343/2015 Z. z. o verejnom obstarávaní a o zmene a doplnení niektorých zákonov v znení neskorších predpisov.

10 Zákon č. 527/2002 Z.z. o dobrovol’ných dražbách a o doplnení zákona Slovenskej národnej rady č. 323/1992 Zb. o notároch a notárskej činnosti (Notársky poriadok) v znení neskorších predpisov. 
- verejným obstarávaním sa podl’a \2 ods. 1 zákona o verejnom obstarávaní rozumejú postupy podl’a tohto zákona, ktorým sa zadávajú zákazky, koncesie a sút’aže návrhov,

- definícia verejnej dražby je ustanovená v \2 písm. a) zákona o dobrovol’ných dražbách;

c) obsahuje okrem implicitného úmyselného zavinenia explicitne vyjadrený motív, ktorý sa vyjadrením stáva obligatórnou súčast'ou subjektívnej stránky trestného činu: ide o motív spôsobit' inému škodu alebo zadovážit' sebe alebo inému prospech,

d) má stanovenú sankciu - trest odňatia slobody vo výmere šest' mesiacov až tri roky,

e) viaže na seba dve kvalifikované skutkové podstaty (\$266 ods. 2 a 3 TZ) s trestnými sadzbami dva roky až osem rokov, resp. sedem rokov až dvanást' rokov, pričom obzvlášt' prit'ažujúcimi okolnost’ami, čiže okolnost'ami podmieňujúcimi použitie vyššej trestnej sadzby sú:

- spôsobenie značnej škody [ods. 2 písm. a)], teda najmenej $26600 €$ (\$125 TZ),

- spáchanie činu z osobitného motívu [ods. 2 písm. b)], čo je bližšie špecifikované v \140 TZ,

- funkcia páchatel'a ako vyhlasovatel'a alebo usporiadatel'a verejnej sút'aže alebo verejnej dražby, člena privatizačnej komisie, licitátora [ods. 2 písm. c)],

- žiadanie, prijatie alebo prijatie slubu majetkového alebo iného prospechu [ods. 2 písm. d)], čiže páchatel' koná ovplyvnený korupciou,

- spáchanie činu závažnejším spôsobom konania [ods. 2 písm. e)], čo je bližšie špecifikované v \ 138 TZ,

- spôsobenie škody vel'kého rozsahu [ods. 3 písm. a)], teda najmenej vo výške $133000 €(\mathbb{S} 125 \mathrm{TZ})$,

- konanie páchatel’a ako člena nebezpečného zoskupenia [ods. 3 písm. b)], čiže zločineckej alebo teroristickej skupiny ( $\left.\int 141 \mathrm{TZ}\right)$;

2. druhá a tretia základná skutková podstata trestného činu ( $\int 267$ a 268 slovenského TZ) postihujú z hl'adiska objektívnej stránky machinácie v súvislosti s verejným obstarávaním alebo verejnom dražbou, pričom:

a) pozostávajú z troch alternatívne vyjadrených druhov konaní:

- prinútenie iného - závažnejším spôsobom konania - aby sa zdržal účasti na verejnom obstarávaní alebo podávaní návrhov verejnej dražbe [ 267 písm. a) a \268 písm. a)], v ktorom prípade môže íst’ o konanie adekvátne vydieraniu,

- poskytnutie, ponúknutie alebo sl’úbenie majetkového alebo iného prospechu inej osobe za to, že sa táto osoba zdrží účasti na verejnom obstarávaní alebo podávaní návrhov na verejnej dražbe [〔 267 písm. b) a \ 268 písm. b)], čo je adekvátne podplácaniu, 
- žiadanie alebo prijatie majetkového prospechu za to, že sa páchatel zdrží účasti na verejnom obstarávaní alebo podávaní návrhov na verejnej dražbe [ $\int 267$ písm. b) a \ 268 písm. b)], čo je adekvátne prijímaniu úplatku.

b) z hl’adiska subjektívnej stránky sa vyžaduje úmyselné zavinenie, avšak nie je špecificky vyjadrený motív,

c) stanovenou sankciou je trest odňatia slobody na jeden rok až pät’ rokov, čiže ide o prečin,

d) kvalifikované skutkové podstaty trestného činu nie sú stanovené.

V súvislosti s rozborom slovenskej právnej úpravy zohl’adňujeme aj legislatívny návrh zmien v zákone o verejnom obstarávaní, ktorý sa nachádza v medzirezortnom pripomienkovom konaní a ktorého účelom je zjednodušit' systém verejného obstarávania a aplikovat' jeho súdnu kontrolu. Úrad pre verejné obstarávanie (ÚVO) uplatnil voči návrhu pripomienku, ${ }^{11}$ v ktorej navrhol aj zmenu ustanovenia \266 slovenského TZ (d’alej len „Pripomienka ÚVO“). ${ }^{12}$

Podl'a českej právnej úpravy trestný čin zjednáni výhody pri zadáni veřejné zakázky, prí verejné soutéži a veŕejné dražbě podl'a \256 českého TZ pozostáva z jednej základnej skutkovej podstaty s nasledujúcimi atribútmi (z ktorých pre českého čitatel’a ako kontrast voči slovenskej právnej úprave vyberáme len tie najdôležitejšie):

a) postihuje sa konanie, ktorým je dojednanie prednosti alebo výhodnejších podmienok niektorému dodávatel’ovi, sút'ažitel'ovi alebo účastníkovi dražby na úkor iných dodávatel’ov alebo sút'ažitel'ov,

11 Priebeh medzirezortného pripomienkového konania aj s pripomienkou Úradu pre verejné obstarávanie, podl'a ktorej sa majú novelizovat' aj ustanovenia slovenského TZ. Dostupné z: https://www.slov-lex. sk/legislativne-procesy/SK/LP/2020/624 [cit. 10. 3. 2021]. Nie je jasné, či vôbec, kedy a v akej podobe sa tento legislatívny návrh s pripomienkami stane súčast’ou platnej a účinnej právnej úpravy.

12 Súčast'ou právnej úpravy $\ 266$ slovenského TZ podla Pripomienky ÚVO má byt' najmä zvýšenie trestných sadzieb a rozšírenie trestného činu na tri základné skutkové podstaty, pričom sa rozlišujú machinácie pri verejnom obstarávaní (ods. 1) a verejnej dražbe (ods. 3) a novou skutkovou podstatou trestného činu (ods. 2) sa má postihovat' spôsobenie väčšej škody, ak ide o zákazku, koncesiu alebo sút’až návrhov, na ktorú sa nevzt’ahuje všeobecne záväzný právny predpis o verejnom obstarávaní. Nová skutková podstata trestného činu by mala byt' formulovaná relatívne komplikovane ako zložená a kumulatívna skutková podstata, so zachovaním zásady subsidiarity trestnej represie (väčšia škoda): „Rovnako ako v odseku 1 sa potrestá osoba podielajúca sa na zadávani zákazky, koncesie alebo sútaže návrhov verejným obstarávatelom alebo obstarávatelom alebo inou osobou, ktorá má povinnost postupovat podla všeobecne záväznébo právneho predpisu o verej-

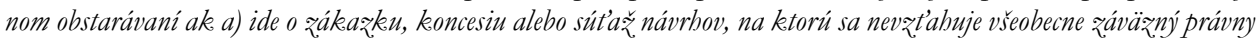
predpis o verejnom obstarávani a b) zadanim zákąkey, koncesie alebo uskutočnením sútaže návrhov spôsobi verejnému obstarávatel'ovi alebo obstarávatelovi alebo inej osobe, ktorá má povinnost postupovat podl’a věeobecne qáväznébo právneho predpisu o verejnom obstarávani vä́čsiu škodu s ciel’om zadovážit' sebe alebo inému prospecb." 
b) konanie sa musí uskutočňovat' v súvislosti so zadaním verejnej zákazky, verejnou sút'ažou alebo verejnou dražbou (objektívna stránka), čiže ide o postup:

- podl'a zákona o zadáváni verejných zakázele ${ }^{13}$, ak ide o veřjejé zákazky, čiže verejné obstarávanie, alebo

- podl'a zákona o veřejných dražbách ${ }^{14}$, príp. podl'a osobitných predpisov o prevode vlastníctva štátu alebo

- podl’a \1772 a nasl. Občanskébo zákonnikea $a^{15}$ (verejná soutěž), avšak pojem veřejná soutěž nemožno chápat' zužujúco len v súvislosti s uvedenými ustanoveniami Občanskébo zákonnika, ale ide o akúkol'vek verejnú sút’až, ktorá je verejne vyhlásená a na ktorej sa môže zúčastnit' neobmedzený okruh subjektov ${ }^{16}$;

c) z hl’adiska subjektívnej stránky sa vyžaduje úmyselné zavinenie s explicitne vyjadreným motívom (škoda, prospech), avšak na naplnenie skutkovej podstaty nemusí skutočne príst' k spôsobeniu škody alebo k zaobstaraniu prospechu - ide o znak tzv. úmyslu, ktorý presahuje objektívnu stránku trestného činu (tzv. obmysl, dolus coloratus) ${ }^{17}$,

d) na základnú skutkovú podstatu nadväzujú tri kvalifikované skutkové podstaty trestného činu [ $\int 256$ ods. 2 písm. a), b), c), resp. ods. 3 a 4 českého TZ].

Taktiež trestný čin s názvom pletichy pri zadáni veřejné zakázky a pri veřejné soutěži podl'a \ 257 českého TZ pozostáva z jednej základnej skutkovej podstaty s nasledujúcimi atribútmi:

a) postihujú sa pletichy (machinácie) v súvislosti so zadáním verejné zakázkyy alebo s veřejnou soutěží, ktoré spočívajú $\mathrm{v}$ niektorom $\mathrm{z}$ nasledujúcich alternatívne vymenovaných konaní:

- prinútenie iného hrozbou násilia alebo inej t’ažkej ujmy, aby sa zdržal účasti v zadávacom konaní alebo verejnej sút’aži [\$257 ods. 1 písm. a) českého TZ], čo je konanie adekvátne vydieraniu,

- poskytnutie, ponúknutie alebo sl'úbenie majetkového alebo iného prospechu inej osobe za to, že sa zdrží účasti v zadávacom konaní alebo verejnej sút'aži [\257 ods. 1 písm. b) českého TZ], čo je adekvátne podplácaniu,

- žiadanie alebo prijatie majetkového alebo iného prospechu za zdržanie sa účasti v zadávacom konaní alebo verejnej sút’aži [〕 257 ods. 1 písm. c) českého TZ], čo je adekvátne prijímaniu úplatku,

- vyvíjanie činnosti smerujúcej k zadaniu verejnej zákazky za neprimerane vysokú alebo inak nevýhodnú cenu, a to na základe dohody s iným uchádzačom alebo

13 Zákon č. 134/2016 Sb. o zadáváni veřejných zakázek v znení neskorších predpisov.

14 Zákon č. 26/2000 Sb. o veřejných dražbách v znení neskorších predpisov.

15 Zákon č. 89/2012 Sb. Občanský zákonník v znení neskorších predpisov.

16 Uznesenie Nejvyššího soudu ČR zo dňa 25. 6. 2020, sp. zn. 5 Tdo 592/2020, bod 16.

17 Uznesenie Nejvyššího soudu ČR zo dňa 23. 11. 2015, sp. zn. 5 Tdo 1475/2015, publikované ako R 14/2018. 
záujemcom [〕 257 ods. 1 písm. d) českého TZ], čo je konanie adekvátne uzatváraniu zakázaných dohôd v rámci ochrany hospodárskej sút'aže,

b) stanovenou sankciou je trest odňatia slobody až na tri roky, resp. trest zákazu činnosti, čiže trestný čin je prečinom,

c) na základnú skutkovú podstatu nadväzujú dve kvalifikované skutkové podstaty [ 257 ods. 2 písm. a), b) a ods. 3 písm. a), b) českého TZ].

Okrem uvedených trestných činov je potrebné vziat' do úvahy aj trestný čin porušeni prè pisù o pravidlech hospodárské soutěže podl’a \248 ods. 2 druhá alinea českého TZ, ktorým sa trestnoprávne postihuje $\mathrm{v}$ rozpore s právnim predpisem o verejných zakáałách porušenie pravidiel zadávacího rízení závažným spôsobom.

\section{Paralelné a divergentné atribúty skúmaných ustanovení}

Slovenský aj český zákonodarca z historického hl’adiska vychádzali zo spoločného základu právnej úpravy, pretože trestnoprávny postih protiprávneho konania spojeného s verejným obstarávaním bol už súčast'ou federálnej právnej úpravy po novele Trestného zákona z roku 1961 (TZ 1961) ${ }^{18}$ zákonom č. 557/1991 Zb. Touto novelou bol zavedený trestný čin machinácií pri verejnej sút’aži a verejnej dražbe (pletichy prri veřejné soutěži a verejné dražbě) podl'a \128a až 128c TZ 1961. Zámerom zákonodarcu bolo reagovat' na negatívne javy, ktoré sa vyskytli v súvislosti s transformáciou riadenej ekonomiky na trhovú ekonomiku a nevyhnutnou kolíziou verejného a súkromného sektora, resp. s prechodom štátneho majetku do vlastníctva súkromných osôb prostredníctvom privatizácie. $^{19}$

Tento trestný čin mal prakticky totožnú štruktúru ako súčasná slovenská právna úprava po rekodifikácii trestného práva hmotného v roku 2005, pozostával z troch základných skutkových podstát, z ktorých prvá postihovala dojednanie prednosti alebo výhodnejších podmienok jednému sút'ažitel'ovi alebo účastníkovi dražby na úkor iných sút'ažitelov a d’alšie dve základné skutkové podstaty trestného činu trestnoprávne reprobovali tri rôzne alternatívy machinácií (pletich) v súvislosti s verejnou sút’ažou alebo verejnou dražbou. Český zákonodarca taktiež prebral pri rekodifikácii prvky z pôvodnej právnej úpravy s určitými korekciami.

Na právnu úpravu verejného obstarávania v Slovenskej i Českej republike v súčasnosti významne vplýva právo Európskej únie, najmä prostredníctvom smernice o verejnom

18 Zákon č. 140/1961 Zb. Trestný zákon v znení neskorších predpisov.

19 „Do drubé skupiny patř́ ty żmèny, jež souviseji s probihajícimi żmènami právního rádu, zejména v oblasti ekonomiky. Isou to ustanoveni reagujicí na néketeré negativni jevy, jež se už v praxi vyskytly a na dalši, jež v budoucnu možno očekávat. Zejména zaslouži pozornosti jednáni, jemuž se v obchodnich kruzich ríká insider trading (』 128), dále pletichy pri verejné soutěži a dražbě, které se již vyskytuji a dále žrejmé budou vyskytovat v rámci privatizace

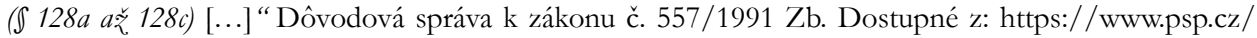
eknih/1990fs/tisky/t1002_01.htm [cit. 25. 11. 2020]. 
obstarávaní $^{20}$ a niektorých d'alších aktov sekundárneho práva EỨ21. Tieto predpisy však neukladajú členským štátom povinnost' ustanovit' trestnost' protiprávneho konania v súvislosti s verejným obstarávaním. Nepriamo táto povinnost' vyplýva v súvislosti s poškodzovaním finančných záujmov EÚ podl'a čl. 3 ods. 2 písm. b) smernice o boji proti podvodom, ktoré poškodzujú finančné záujmy Únie ${ }^{22}$, podla ktorého majú členské štáty povinnost' zabezpečit', že podvod poškodzujúci finančné záujmy Únie, pokial' ide o výdavky súvisiace s verejným obstarávaním, predstavuje trestný čin. Tento podvod je v smernici špecifikovaný konkrétnymi tromi alternatívami konania ${ }^{23}$. V tomto zmysle je možný aj jednočinný súbeh trestných činov, ktorých objektom je ochrana riadneho priebehu verejného obstarávania (『 266 až 268 slovenského TZ, 』 256, 257 českého TZ), a trestných činov, ktorých objektom je ochrana finančných záujmov EÚ. ${ }^{24}$

\subsection{Ustanovenia \266 ods. 1 slovenského TZ a \256 a 248 ods. 2 českého TZ}

Základná skutková podstata trestného činu zjednáni výhody pri zadáni verejné zakázky, pri veřjné soutéži a veřejné dražbě podl'a \256 českého TZ je z hl'adiska znakov objektívnej stránky (dojednanie prednosti alebo výhodnejších podmienok) i subjektívnej stránky (úmysel a vyjadrený motív) adekvátna základnej skutkovej podstate trestného činu machinácií pri verejnom obstarávaní a verejnej dražbe podl’a \266 slovenského TZ. Oba trestné činy nadväzujú svojím obsahom na predchodcu v ust. \128a TZ 1961. ${ }^{25}$

20 Smernica Európskeho parlamentu a Rady 2014/24/EÚ z 26. februára 2014 o verejnom obstarávaní a o zrušení smernice 2004/18/ES (Ú. v. EÚ L 94, 28. 3. 2014).

21 Smernica Európskeho parlamentu a Rady 2014/25/EÚ z 26. februára 2014 o obstarávaní vykonávanom subjektmi pôsobiacimi v odvetviach vodného hospodárstva, energetiky, dopravy a poštových služieb a o zrušení smernice 2004/17/ES (Ú. v. EÚ L 94, 28. 3. 2014) a d’alšie.

22 Smernica Európskeho parlamentu a Rady (EÚ) 2017/1371 z 5. júla 2017 o boji proti podvodom, ktoré poškodzujú finančné záujmy Únie, prostredníctvom trestného práva (Ú. v. EÚ L 198, 28. 7. 2017).

23 Čl. 3 ods. 2 písm. b) smernice o boji proti podvodom, ktoré poškodzujú finančné záujmy Únie: „Na účely tejto smernice podvod poškodzujúci finančné záujmy Únie predstavuje: [...] b) pokial' ide o výdavky súvisiace s verejným obstarávaním, aspoň pokial' k nemu došlo v úmysle získat' pre páchatel'a alebo inú osobu neoprávnený prospech, a to poškodenim finančných záujmov Únie, akékolvek konanie alebo opomenutie týkajúce sa:

i) použivania alebo predkladania falšvaných, nesprávnych alebo neúplných výkazov alebo dokeladov, ktoré majú za následok spreneveru alebo neoprávnené zadržiavanie finančných prostriedkov alebo aktív z rozpočtu Únie alebo z.rozpočtov spravovaných Úniou, alebo v jej mene;

ii) neposkytnutia informácii v rozpore s konkétnou povinnostou, a to s rovnakým následkom; alebo

iii) zneužitia takýchto finančných prostriedkov alebo aktiv na iné účly, než na ktoré boli pôvodne poskytnuté, ketoré poškodzuje finančné záujmy Únie; [...]"

24 Pozri ŠANTA, Ján. Ochrana a poškodzovanie finanǒných záujmov Európskej únie. Bratislava: Akadémia Policajného zboru v Bratislave, 2018, s. 118 a nasl. a tam citované rozhodnutia.

25 K tomu pozri uznesenie Nejvyššího soudu ČR zo dňa 30. 6. 2020, sp. zn. 5 Tdo 1559/2018, bod 75: „V zásadě shodné znaky obsahovala základni skutková podstata ustanoveni \128a odst. 1 tr. zákona, prestože neob-

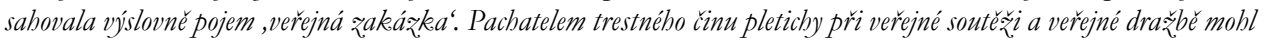
být ten, kdo v souvislosti s veŕejnou soutěži nebo veřejnou dražbou v úmyslu zpuisobit jinému škodu nebo opatrit sobě nebo jinému prospěch zjednal některému soutěžiteli nebo účastniku dražby prédnost nebo výhodnèjsi podminkey na úkeor jiných soutézitelu." 
Z hladiska vyjadreného motívu a absencie znaku spôsobenej škody v základnej skutkovej podstate teda postačuje, aby úmysel páchatel’a len smeroval k spôsobeniu škody alebo zadováženiu prospechu, pričom toto nemusí skutočne nastat'. V tom sa obe právne úpravy zhodujú. ${ }^{26}$

Zhodnost' právnych úprav má však svoje výnimky, najmä v objektívnej stránke skutkovej podstaty trestného činu.

Predmetná česká právna úprava - na rozdiel od svojho slovenského pendanta - obsahuje alternatívu konania $\mathrm{v}$ rámci objektívnej stránky, ktorá spočíva $\mathbf{v}$ bližšie nešpecifikovanom konaní, ktoré je $\mathrm{v}$ rozpore so všeobecne záväzným právnym predpisom o verejnom obstarávaní pri inom trestnom čine, ktorým je trestný čin porušení préedpisù o pravidlech hospodárské soutěže podl’a \248 ods. 2 druhá alinea českého TZ. Česká právna úprava ako znak skutkovej podstaty požaduje porušenie pravidiel závažným spôsobom, čím sa odlišujú menej závažné porušenia zákona č. 134/2016 Sb. o zadáváni verejných zakázeke, ktoré nie sú trestnoprávne relevantné, od závažných porušení tohto zákona, ktoré majú trestnoprávnu relevanciu. Rozlišovacím kritériom je, že závažným porušením je také porušenie, ktoré sa podstatne odchyl’uje od stavu vyžadovaného týmto zákonom. ${ }^{27}$

V slovenskej právnej úprave je možné pod konanie $\mathrm{v}$ rozpore so všeobecne záväzným právnym predpisom o verejnom obstarávaní alebo verejnej dražbe znak objektívnej stránky subsumovat' prakticky akékol'vek porušenie osobitného zákona, ktoré však dosahuje úroveň trestnoprávnej relevancie a zároveň je spojené s motívom získania prospechu alebo spôsobenia škody. Na tejto právnej úprave zotrváva aj navrhované nové znenie \266 slovenského TZ podl'a Pripomienky ÚVO, ktorá dokonca počíta s rozšírením trestnej represie tým, že dokonaným trestným činom má byt' pokus konania v rozpore so všeobecne záväzným právnym predpisom o verejnom obstarávaní. ${ }^{28}$

V prípade českej i slovenskej právnej úpravy ide o alternatívu konania, ktorá z hl’adiska rozsahu kriminalizácie trpí značným stupňom neurčitosti, ked’že zákonodarca jasne nevymedzil, aké konkrétne konanie (porušenie osobitného zákona) napĺňa znak skutkovej podstaty trestného činu, a teda aký charakter a spoločenskú závažnost' musí mat' porušenie osobitného zákona. Prijatel'nost' takejto právnej úpravy je hraničná z hl’adiska možného porušenia zásady nullum crimen sine lege certa. Problém tzv. kaučukových

26 Napr. uznesenie Nejvyššího soudu ČR zo dňa 23. 11. 2015, sp. zn. 5 Tdo 1475/2015, publikované ako R 14/2018; Resp. ŠANTA, Ján. Machinácie pri verejnom obstarávani podla Trestnébo zákona Slovenskej republiky. Dostupné z: https://www.ja-sr.sk/files/Machinacie_JUDr_Santa.pdf [cit. 1. 12. 2020].

27 ŠÁMAL, Pavel. \248. In: ŠÁMAL, Pavel a kol. Trestní qákoník. 2. vyd. Praha: C. H. Beck, 2012, s. 2494-2539.

28 Podl’a Pripomienky ÚVO má mat' ustanovenie \ 266 ods. 1 slovenského TZ nasledujúce znenie: „,(1) Kto $v$ súvislosti s verejným obstarávaním v úmysle spôsobit' inému škodu alebo zadováżit’ sebe alebo inému prospech

a) koná v rozpore so v̌́eobecne záväzným právnym predpisom o verejnom obstarávani alebo sa o to pokúsi alebo

b) dojedná niektorému hospodárskemu subjektu prednost' alebo výhodnejšie podmienky na úkor iných hospodárskych subjektov alebo sa o to pokéusi, potrestá sa odñatim slobody na šest' mesiacov až pät' rokov." 
ustanovení v trestnom zákone ${ }^{29}$, ktoré je možné účelovo nat'ahovat' do rôznych rozmerov, tak môže nadobudnút' až ústavnoprávny rozmer, pričom sa v trestnom zákonodarstve vyskytoval pred rokom $1989^{30}$ i neskôr.

Mantinelom aplikácie trestnej represie pri takto formulovanej alternatíve objektívnej stránky skutkovej podstaty trestného činu je výlučne zásada subsidiarity trestnej represie, resp. postavenia trestného práva ako prostriedku ultima ratio ${ }^{31}$, teda jeho uplatnenie ako najostrejšieho meča ${ }^{32}$ medzi právnymi odvetviami. Pri hospodárskych trestných činoch sa rozsah trestnoprávnej represie má obmedzovat' na nevyhnutnú kultiváciu podnikatel'ského prostredia a posilnenie spol’ahlivosti rozhodovania vlastníkov, štatutárnych orgánov a manažmentu. ${ }^{33} \mathrm{Na}$ základe toho je možné príst' k záveru, že niektoré porušenia zákona o verejnom obstarávaní nie sú natol’ko závažné, že by zakladali trestnoprávnu zodpovednost'. Napokon, zásadu subsidiarity trestnej represie potenciálne je možné uplatnit' aj pri naplnení druhej alternatívy objektívnej stránky - dojednanie prednosti alebo výhodnejších podmienok, pričom možno do úvahy brat' rôzne kritériá závažnosti činu: napr. predchádzajúci pracovnoprávny (regresný) postih, súbeh viacerých trestných činov atd'. ${ }^{34}$

Známe stanovisko Nejvyšš́ho soudu ČR vo veci aplikácie zásady subsidiarity trestnej represie je dobre použitel’né na postih protiprávnych aktivít v súvislosti s verejným obstarávaním tak v českých ako i slovenských právnych podmienkach: „Zásadně tedy platí, že každy protiprávni čin, který vykazuje všechny znaky uvedené v trestním zákoniku, je trestným činem a je tréba vyvodit trestni odpovědnost za jeho spácháni. Tento závěr je však v př́padě ménè qávažných trestných činù korigován použitím zásady subsidiarity trestní represe ve smyslu $\int 12$ odst. 2 tr. zákoniku, podle niž trestni odpovědnost pachatele a trestněprávni disledky s ni spojené lze uplatñovat jen v prípadech společensky škodlivých, ve kterých nepostačuje uplatnèni odpovédnosti podle jiného právního

29 Napr. k tomu SOLNAŘ, Vladimír. Systém československébo trestního práva. Základy trestni odpovédnosti. Praha: Academia, 1972, s. 55: „Presné a jasné skutkové podstaty trestných činu jsou diležitou zárukou zákonnosti v trestním právu. [...] Jsou ov šem značné rozdíly mezi skutkovými podstatami kaučukovými bezjasných hranic a skutkovými podstatami presně a konkrétnè vymezuenými."

30 Napr. znak živenia sa nekalým spôsobom pri trestnom čine príživníctva podl’a \ 203 TZ 1961 do roku 1990, resp. znaky skutkových podstát trestných činov špekulácie podl’a $\int 117$ TZ 1961, podvracania republiky podl'a S 98 TZ 1961 a d'alších.

31 Napr. TIBITANZLOVÁ, Alena a Jiří MULÁK. Ještě několik poznámek na téma zásady subsidiarity trestní represe. Trestněprávní revue, roč. 17, 2018, č. 5, s. 115-120; Ďalej ČENTÉŠ, Jozef a Ján ŠANTA. Princíp ultima ratio a vybrané aspekty ekonomickej kriminality. In: Trestné právo ako ultima ratio - bmotnoprávne a procesnoprávne aspekty. Zborník príspevkov z. 1. sekcie medzinárodnej vedeckej konferencie Bratislavské právnické fórum, Bratislava: Univerzita Komenského, Právnická fakulta, 2016, s. 31-41.

$32 \mathrm{~K}$ tejto metafore ROSTALSKI, Frauke. Der Tatbegriff im Strafrecht. Entwurf eines im gesamten Strafrechtssystem einheitlichen normativ-funktionalen Begriffs der Tat. Tübingen: Mohr Siebeck, 2019, s. 16.

33 NETT', Alexander. Ke změnám trestního práva na úseku hospodářské trestné činnosti a k zásadě ultima ratio. Bulletin advokacie, 2009, č. 10, s. 77-81.

34 Uznesenie Nejvyššího soudu ČR zo dňa 22. 4. 2020, sp. zn. 5 Tdo 1532/2019, bod 39. 
predpisu. “35 V tomto zmysle, ak ide o posúdenie trestnoprávnej relevancie konania v rozpore so všeobecne záväzným právnym predpisom o verejnom obstarávaní podl’a \266 ods. 1 slovenského 'TZ, je potrebné najmä zvažovat' zodpovednost' za správny delikt podl'a \182 zákona o verejnom obstarávaní, resp. za priestupok podl’a \182a zákona o verejnom obstarávaní. Naopak, spoločenská závažnost' sa zvyšuje, ak páchatel' zabraňuje sút'aženiu o zákazku niekol'kými navzájom si konkurujúcimi subjektmi, aby obstarávatel' mohol uzavriet' skutočne najvýhodnejšiu zmluvu. ${ }^{36}$

'Trestnoprávnu relevanciu budú mat' teda najmä vážne porušenia základných povinností verejného obstarávatel’a a obstarávatel’a podl'a $\ 10$, resp. 11 zákona o verejnom obstarávaní. Predovšetkým pôjde o vážne porušenia princípu rovnakého zaobchádzania, princípu nediskriminácie hospodárskych subjektov, princípu transparentnosti, princípu proporcionality a princípov hospodárnosti a efektívnosti podl'a $\int 10$ ods. 2 zákona o verejnom obstarávaní. Tieto princípy sú v zákone ustanovené na základe transpozície čl. 18 smernice o verejnom obstarávaní a na ich výklad sa vzt’ahuje rozhodovacia činnost' Súdneho dvora Európskej únie.

Verejní obstarávatelia sú v celom konaní povinní dodržiavat' tieto princípy. ${ }^{37}$ Osobitne dôležitý je princíp rovnakého zaobchádzania, teda zákazu diskriminácie, ktorý vyžaduje rovnaké podmienky pre všetky sút’ažiace podniky z hl’adiska podávania ponúk, teda rovnakú príležitost’ formulovania znenia ponúk. ${ }^{38}$ Rovný prístup k verejným zákazkám je sprevádzaný rovnost'ou možného úspechu vo verejnom obstarávaní a prejavuje sa v rovných podmienkach pre všetkých uchádzačov, ktorí spĺňajú podmienky

35 Stanovisko Nejvyššího soudu ČR zo dňa 30. 1 2013, sp. zn. Tpjn 301/2012, publikované ako R 26/2013.

36 Adekvátne k tomu uznesenie Nejvyššího soudu ČR zo dňa 25. 6. 2020, sp. zn. 5 Tdo 592/2020, bod 18: „Naopak je společenská škodlivost zvyšována tím, že obvinèní zabránili vưbec vzniku jakéhokoli náznaku soutěžení o veŕejnou zakázku, v niž by o její predmèt vážně usilovalo několik navzájem si konkurujicich subjektů tak, aby zadavatel mobl uzavrít skutečné pro něbo nejvýhodnèjsí smlouvu na provedení soutěženého díla. V podstatě nenastala ani teoretická možnost, aby se tak stalo, nebot'spoluobvinèni od počátku vžali prüběb celého zadávacího rizeni do vlastnich rukou a osloveni dodavatelé predstavujici tzu. ,krovi" nevykazovali jakýkoli vážný zájem o vitězství v soutěži. Lze pripustit, že menší společenská škodlivost manipulovaného zadávacího ř́rzeni by mobla nastat napríklad v situaci, v niž by zadavatel sdělil některému uchazeči neveřejnou informaci, která nebude pro zadání veřejné zakázky stěžejní, což však roz̧hodně nebyl daný př́pad. Spoluobvinèni nejprve určili vitězného dodavatele a následně organizovali zadávaci rízeni jemu na míru zásadnè v rozporu se zásadou transparentnosti a rovnébo zacházení za současnébo predstíráni, že po formálni stránce byla verejná zakážka zadána v souladu se zákonem o verejných zakázkách, resp. jeho obecnými zásadami. Pri výkladu a aplikaci ustanoveni $\int 12$ odst. 2 tr. zákoníku bylo rovněž významné, že posuzovaným skutkem spoluobvinèni naplnili znaky dvou trestných činü, což rozhodně nesvédči o vyjimečných okolnostech, které by mobly vyloučit potrebu uplatnit prostredky trestního práva a z nèj vyplývajici principu ,ultima ratio."“ [Pozn.: vyznačil autor].

37 Rozsudok Súdneho dvora zo dňa 20. 9. 2018, Montte SL, C-546/16, ECLI:EU:C:2018:752, bod 38.

38 „Zásada rounosti zaobchádzania s uchádzačmi, ketorej cielom je podporovat’ rozvoj zdravej a účinnej hospodárskej sút’ą̌e medzi podnikmi, ktoré sa zúčastňujú na verejnom obstarávaní, prikazuje, aby všetci uchádz̨ači mali rovnaké príležitosti pri formulovaní żnenia svojich ponúk, a preto vyžaduje, aby tieto ponuky podliehali rovnakým podmienkam pre všetky sút’ažiace podniky [...]“. Rozsudok Súdneho dvora zo dňa 12. 3. 2015, eVigilo, C-538/13, ECLI:EU:C:2015:166, bod 33. 
obstarávatel'a. ${ }^{39}$ Nediskriminačné zaobchádzanie a transparentnost' konania sú spojené aj s technickými špecifikáciami pri vyhlasovaní verejného obstarávania - so spôsobom ich formulovania a ich výberom; technické špecifikácie musia umožňovat' rovnaký prístup pre všetkých uchádzačov a nesmú vytvárat' neopodstatnené prekážky. ${ }^{40}$ Prísne posudzovanie povinnosti rovnakého zaobchádzania je zdôraznené aj tým, že k zvýhodneniu (resp. znevýhodneniu) súkromného podniku nesmie príst’ ani spoluprácou medzi verejnými obstarávatel'mi. ${ }^{41}$

Taktiež dôležitým je princíp transparentnosti, ktorý znamená povinnost' verejného obstarávatel'a - v oznámení o vyhlásení verejného obstarávania alebo v sút'ažných podmienkach - formulovat' podmienky a postupy zadania zákazky jasne, presne a jednoznačne, aby boli pre uchádzačov zrozumitel'né a aby boli ponuky uchádzačov preskúmatel'né z hl'adiska splnenia kritérií obstarávania. ${ }^{42}$ Transparentnost' predpokladá zaistenie čo najvyššej miery informovanosti účastníkov, obstarávatel’ov, ale aj verejnosti o priebehu verejného obstarávania. ${ }^{43}$ Tieto princípy vo svojom súhrne vyžadujú objektívnost' zadávacích kritérií, objektívnost' porovnania a vyhodnotenia ponúk tak, aby bola zaručená účinná hospodárska sút'až. Tieto kritériá teda nesmú dávat' verejnému obstarávatel’ovi neobmedzenú slobodu výberu. ${ }^{44}$ To znamená, že tak, ako je v záujme zachovania princípu právnej istoty nevyhnutné formulovat' dostatočne určitým spôsobom znaky skutkovej podstaty trestného činu, tak je potrebné dostatočne určitým spôsobom formulovat' kritériá výberu pri verejnom obstarávaní, avšak na druhej strane určitá formulácia nesmie neodôvodnene vylučovat' subjekty, nesmie byt' diskriminačná.

K predmetným princípom Nejvyšši soud ČR uviedol, že ich uplatňovanie má zabránit' páchaniu trestnej činnosti spojenej s verejným obstarávaním v jej typických formách: „Právě priběb zadávacího rízeni ovládaný tèmito tremi základními zásadami má zabránit posuzovanému drubu trestné činnosti, jejiž. podstatou bývá účlový výbèr predem určeného vitèze pachatelem či spolupachateli a nastaveni takových podminek zadávacíbo rízeni tak, aby bylo dosaženo tohoto cíle, k. čemuž bývá nutná součinnost tzv. nastrčených soutěžitelu, uchazeču, kteř jsou obeznámeni se svou roli prèdstíranébo zájmu o vitèzství, často za finančni odmènu či prìslib jiné výhody, napr. subdodavatelské služby, vitězstvi v jiné veřejné soutěži, apod."

\footnotetext{
39 Uznesenie Nejvyššího soudu ČR zo dňa 30. 6. 2020, sp. zn. 5 Tdo 1559/2018, bod 77.

40 Rozsudok Súdneho dvora z 10. 5. 2012, Komisia vs. Holandsko, C-368/10, ECLI:EU:C:2012:284, bod 62.

41 Rozsudok Súdneho dvora z 28. 5. 2020, Informatikgesellschaft für Software-Entwickelung (ISE) mbH, C-796/18, ECLI:EU:C:2020:395, bod 76

42 Rozsudok z 10. 5. 2012, Komisia vs. Holandsko, C-368/10, ECLI:EU:C:2012:284, bod 109 a tam citovaná judikatúra.

43 Uznesenie Nejvyššího soudu ČR zo dňa 30. 6. 2020, sp. zn. 5 Tdo 1559/2018, bod 77.

44 Rozsudok Súdneho dvora z 10. 5. 2012, Komisia vs. Holandsko, C-368/10, ECLI:EU:C:2012:284, bod 87.

45 Uznesenie Nejvyššího soudu ČR zo dňa 25. 6. 2020, sp. zn. 5 Tdo 592/2020, bod 14.
} 
Porušenie týchto princípov sa prejaví v porušení d’alších základných povinností verejného obstarávatel'a a obstarávatel'a, napr. postupy verejného obstarávania sa nesmú vykonávat' s motívom nedovoleného uplatnenia výnimky zo zákona o verejnom obstarávaní alebo narušenia hospodárskej sút’aže bezdôvodným zvýhodnením alebo znevýhodnením určitých subjektov (〔 10 ods. 3 zákona o verejnom obstarávanî). Nediskriminácia, rovnaké zaobchádzanie a transparentnost' - ako základné a t’ažiskové princípy európskej i vnútroštátnej právnej úpravy - môžu byt' závažným spôsobom porušené postupom $\mathrm{v}$ rozpore s ustanoveniami zákona, ktorých účelom je zabezpečit' verejnost' výzvy.

$\mathrm{V}$ tomto zmysle je potrebné v slovenských podmienkach poukázat’ na prípad známy ako tzv. nástenkový tender, teda verejné obstarávanie na Ministerstve výstavby a regionálneho rozvoja SR s celkovou hodnotou zákazky viac ako 97,6 milióna €, pre ktorý boli právoplatne podl'a \266 ods. 1, ods. 3 slovenského TZ odsúdení dvaja exministri výstavby. Súd identifikoval celý rad protizákonných postupov odsúdených. Obstarávanie sa vykonávalo bez odborne spôsobilej osoby ${ }^{46}$. Výzva mala byt' podl'a skutkovej vety rozsudku „zverejnená“ na informačnej tabuli za zamknutými dverami na chodbe neprístupnej verejnosti, ako uviedol Najvyšší súd SR: „[... [ v rozpore s $\int 99$ ods. 3 zákona č. 25/2006 Z. ₹. vôbec neuverejnili Výzvu na predkladanie ponúk, pričom v rozpore so skutočnostou deklarovali ako miesto jej zverejnenia informačnú tabul'u na I. poschodi budovy ministerstva, a to vobdobi styroch pracovných dní - od 17. do 22. mája 2007, č́m znemožnili účast' vo verejnej sútaži neobmedzenému počtu uchádzačov a záujemcov, $v$ dôsledku čoho sa KONZORCIUM stalo jediným sútažitel'om v takto ,vyhlásenom verejnom obstarávaní [...] “47. Takýto postup mal viest' - ako správne Nejvyšš́ sond $\check{C} R$ vyššie vystihol podstatu a charakter tejto trestnej činnosti - k účelovému výberu vopred určeného vít’aza, teda len $\mathbf{k}$ „fingovaniu“ skutočného verejného obstarávania: „_p]odl'a mienky odvolacieho súdu, v posudzovanom prípade išlo od začiatku o vedomú, úmyselnú a systematickú činnost, ketorá smerovala ke úplnému eliminovaniu sút'ažného prostredia. Laicky povedané, obžalovani spolu s d’alšmi osobami proces verejnébo obstarávania len fingovali, ked’̌̌e quákazka bola od začiatku určená pre KONZORCIUM.“48 „Dokonalost'“ zločinu manipulovaného,

46 V rozpore s $\int 116$ ods. 1 vtedy účinného zákona č. 25/2006 Z. z.

47 Rozsudok Najvyššieho súdu SR zo dňa 15. 11. 2018, sp. zn. 5To/2/2018, s. 3. Rozhodnutie získalo ocenenie Judikát roka 2019. „Zverejnenie“ sa však podl'a skutkových zistení nevykonalo ani na tejto nástenke: „V’́zva na predkladanie ponúk, ale aj d’alšie podklady [...] vypracované v procese verejnébo obstarávania boli vytvárané a pripomienkované dávno po tom, ako mala byt' V'́zva na predkladanie ponúk zverejnená, dokonca po tom, ako mala byt’ podpisaná Zmluva o poskytovaní služieb [...]. Zo zaistených súborov tiež plynie, že v čase, ked' malo byt' verejné obstarávanie ukončené, ešte nebol pripravený menovaci dekrét pre členov hodnotiacej komisie a dokonca ani ponuka KONZORCIA [...]. Je teda evidentné, že v deklarovanom obdobi od 17. - 22. mája 2007 predmetná výzva na nástenke, ale ani nikede inde visiet' nemobla."Ibid., s. 36-37.

48 Ibid, s. 30. 
resp. predstieraného verejného obstarávania bola $\mathrm{v}$ predmetnom prípade zvýraznená aj tým, že jeho kontrolu mala vykonávat' osoba, ktorá ho pripravovala. ${ }^{49}$

$\mathrm{Na}$ druhej strane nie každé porušenie základných povinností verejného obstarávatel’a musí mat' trestnoprávnu relevanciu. Ako príklad možno uviest' nesplnenie alebo len čiastočné splnenie povinnosti verejného obstarávatel'a ,po skončeni kalendárneho šturtroka uverejnit' v profile súbrnnú správu o zmluvách so zmluvnými cenami vyššimi ako $1000 €$ "podla \10 ods. 10 zákona o verejnom obstarávaní a množstvo d’alších menej významných porušení zákona.

Porušenie uvedených základných princípov, teda konanie v rozpore so zákonom o verejnom obstarávaní môže zároveň viest' aj k súčasnému naplneniu druhej alternatívy objektívnej stránky skutkovej podstaty trestného činu podl'a \266 ods. 1 slovenského TZ dojednanie prednosti alebo výhodnejších podmienok..$^{50}$

V porovnaní s uvedeným je tento znak jedinou formou konania podl’a \256 ods. 1 českého TZ a jeho naplnenie sa taktiež viaže na porušenie zásad zadávání veřejných zákaz̧ek podl'a $\int 6$ zákona o zadáváni veřejných zakázek. Pojmy prednost' a výhodnejšie podmienky sa v českej a slovenskej právnej úprave vykladajú v zásade rovnako. Prednost’ou je akékol’vek zvýhodnenie, ktoré sa týka časového predstihu, napr. oznámenie rozhodujúcich termínov pri verejnom obstarávaní pred ich verejným vyhlásením. Výhodnejšími podmienkami sa myslia akékol'vek iné podmienky, ktoré zvýhodňujú sút'ažitel’a pred inými, napr. oznámenie údajov o obsahu návrhov - realizačných a cenových ponúk iných sút’ažitel'ov. ${ }^{51}$ Vytvorenie výhodnejších podmienok môže spočívat' aj v potlačení sút'ažného prostredia, teda obmedzením účasti dodávatel'ov, ktorí by v danom čase a priestore spíňali podmienky na realizáciu sút'aženého diela. ${ }^{52}$

V tomto zmysle stanovuje česká právna úprava užší rozsah kriminalizácie (len jedna alternatíva konania) s jeho presnejším vymedzením ako slovenská právna úprava, teda obmedzuje sa len na dojednanie prednosti alebo výhodnejších podmienok. Na druhej strane právna úprava podl’a \ 256 českého TZ poskytuje širší rozsah kriminalizácie z hl’adiska

49 Ibid., s. 44: „A boci predmetná žiadost’ bola formálne adresovaná JUDr. V. akoo vedúcej odboru kontroly ÚVO [pozn. - Úrad pre verejné obstarávanie], doručená bola JUDr. M.B., vtedajšej vedúcej služobného úradu ÚVO, ketorá s výkonom kontroly nemala mat' nič spoločné. Ide pritom o tú istú osobu, sktorou sa mala obžalovaná Ing. E.F. na popud JUDr. L. podiel'at' na priprave podkladov pre verejné obstarávanie (vid' nižšrie k zrušujúcej časti obžalovanej Ing. E.F.). Inými slovami, kontrola verejnébo obstarávania bola pod dobladom osoby, k.torá sa takmer s určitost’ou na jej priprave podiel'ala.“

50 Pozri právnu vetu výroku predmetného rozsudku Najvyššieho súdu SR: „[...] obžalovani Ing. A.B. a Ing. PhDr. C.D. spoloćným konaním v súvislosti s verejným obstarávaním v úmysle zadovážit' inému prospech konali v rozpore so všeobecne záväzným predpisom o verejnom obstarávani a dojednali niektorému sútažitelovi výhodnejšie podmienky na úker iných sút'ažitel'ov a tento čin spáchali ako vyblasovatel' (Ing. A.B.) a usporiadatel' (Ing. PhDr. C.D.) verejnej sút’aže a spôsobili tým škodu vel'kého rozsahu [...]".

51 ŠÁMAL, Pavel. \ 256. In: ŠÁMAL, Pavel a kol. Trestni zákoník. 2. vyd. Praha: C. H. Beck, 2012, s. 2618-2627; Porovnaj ŠANTA, J. Ochrana a poškodzovanie finančných záujmov Európskej únie. Bratislava: Akadémia Policajného zboru v Bratislave, 2018, s. 120.

52 Uznesenie Nejvyššího soudu ČR zo dňa 25. 6. 2020, sp. zn. 5 Tdo 592/2020, bod 17. 
vecnej pôsobnosti ochrany: slovenská právna úprava poskytuje ochranu riadnemu priebehu verejného obstarávania a verejnej dražby, zatial’čo česká právna úprava poskytuje ochranu riadnemu priebehu širšieho okruhu procesov: zadáni veřejné zakázky, veřejná soutěž a veřejná dražba. Ochrana podl'a \266 slovenského TZ sa nevzt'ahuje ${ }^{53}$ na verejnú sút'až podl'a \847 a nasl. slovenského Občianskeho zákonníka ${ }^{54}$ a obchodnú verejnú sút’až podl’a \ 281 a nasl. slovenského Obchodného zákonníka ${ }^{55}$. Navyše pojem verejná soutěž sa vykladá širšie než len podl'a ustanovení Občanského zákonník a $a^{56}$, čo rozsah ochrany - kriminalizácie ešte zvýrazňuje. Z hl'adiska použitých pojmov „,v súvislosti s verejným obstarávaním“a „,v souvislosti se zadáním verejejé zakáaky" je možné konštatovat’ rovnaký rozsah kriminalizácie, hoci v Českej republike sa vyskytli názory o užšom chápaní pojmu, ktoré boli judikatúrou odstránené. ${ }^{57} \mathrm{~V}$ tejto súvislosti Nejuyš̌sí sond $\check{C} R$ uviedol, že predmetné ustanovenie nie je blanketovou, ani odkazovacou skutkovou podstatou, pretože sa ani všeobecne, ani konkrétne neodvoláva na mimotrestný právny predpis, ktorého porušením je podmienená trestná zodpovednost'. ${ }^{58}$ 'Týmto sa však vzhl’adom na vyššie uvedené - slovenská a česká právna úprava odlišujú, pretože prvá alternatíva konania $\mathrm{v}$ objektívnej stránke „koná v rozpore so všeobecne záväzným právnym predpisom o verejnom obstarávani alebo verejnej dražbe "podl'a \266 ods. 1 slovenského TZ priamo odkazuje na konkrétne mimotrestné právne predpisy a nie je možné identifikovat' taký výklad, ktorý by výpočet týchto predpisov rozširoval na neurčitý okruh. Výnimku tu tvorí len kvalifikovaná skutková podstata podl'a \266 ods. 2 písm. c) slovenského TZ, ktorá používa pojem verejná sút’až, ktorý je pojmom širším ako verejné obstarávanie a zahŕňa sút’aže realizované aj podl’a iných zákonov. ${ }^{59}$ Ide však len o nepresnost' formulácie pri rekodifikácii.

53 Pozri KORDÍK, Marek. \266. In: BURDA, Eduard, Jozef ČENTÉŠ, Juraj KOLESÁR, Jozef ZÁHORA a kol. Trestný zákon. Osobitná čast'. Komentár. II. diel. 1. vyd. Praha: C. H. Beck, 2011, s. 735-736.

54 Zákon č. 40/1964 Zb. Občiansky zákonník v znení neskorších predpisov.

55 Zákon č. 513/1991 Zb. Obchodný zákoonnik v znení neskorších predpisov.

56 Pozri vyššie.

57 Uznesenie Nejvyššího soudu ČR zo dňa 29. 3. 2017, sp. zn. 5 Tdo 1106/2016, publikované ako R 1/2019; Ďalej uznesenie Nejvyššího soudu ČR zo dňa 31. 5. 2017, sp. zn. 5 Tdo 1364/2016, publikované ako R 6/2018; podobne aj uznesenie Nejvyššího soudu ČR zo dňa 25. 6. 2020, sp. zn. 5 Tdo 592/2020.

58 Ibid., R 1/2019: „Ustanoveni \ 256 tr. zákoníku o trestném činu zjednáni výhody pri zadáni veřjné zakázky, pri verejné soutěži a verejné dražbě neni normou s blanketni, ani sodkazovaci skutkovou podstatou, nebot' se nedovolává ani obecně, ani konkrétně mimotrestního predpisu, který by bylo třba užit nebo jehožporušením je podminèna trestni odpovědnost."; Rovnako uznesenie Nejvyššího soudu ČR zo dňa 30. 6. 2020, sp. zn. 5 Tdo 1559/2018, bod 78.

59 Rozsudok Najvyššieho súdu SR zo dňa 15. 11. 2018, sp. zn. 5 To 2/2018, s. 63-64: „Legálny pojem,verejná sút'až' je totiž omnoho širší a popri sút'ažiach realizovaných formou „verejného obstarávania“ podl'a zákona č. 25/2006Z. z., zahfrña aj verejné sút’aže podl’a $\int 847$ a nasl. Obč. zák., resp. obchodné verejné sút'aže podl’a $\int 281$ a nasl. Obch. zák. O uvedenom svedči aj bistorický vývoj skutkovej podstaty, ktorá bola do \128a zákona c. 140/1961 Zb. Trestný zákon zavedená zákonom č. 557/1991 Zb. s názvom machinácie pri verejnej sútą̌i a verejnej dražbe. [...] Z ústavnoprávnych dôvodov sa však zákonodarca roz̧bodol pre siršiu formuláciu, tak aby dopadala na akékolvek ovplyvňovanie verejnej sút’ǎ̌e, bez obl'adu na to, či sa týka majetku štátu alebo inébo subjektu. [...] Až rekodifikáciou Trestného zákona (prijatím zákona č. 300/2005 Z. z.) zákonodarca v ods. 1 zúžil rozsah chránených „verejných sút'aži" 'len na tie, ktoré boli realizované formou, verejného obstarávania' podl'a osobitného predpisu. Túto zmenu však opomenul premietnut' do kvalifikovanej skutkovej podstaty v ods. 2, ketorá nad'alej (obsolétne)

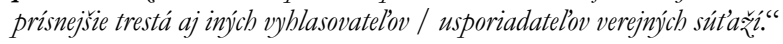


Pri skúmaní kvalifikovaných skutkových podstát vo vzt’ahu k základným skutkovým podstatám trestných činov podl'a \266 ods. 1 slovenského TZ a \256 českého TZ obsahujú tieto ustanovenia navzájom adekvátne prvky, ktoré sú okolnost’ami podmieňujúcimi použitie vyššej trestnej sadzby. Obe právne úpravy ustanovujú ako obzvlášt' prit’ažujúce okolnosti, ak páchatel' spácha čin ako vyhlasovatel' alebo usporiadatel' verejnej sút’aže, verejnej dražby, resp. ako licitátor a slovenská právna úprava do tohoto výpočtu zarad’uje aj postavenie člena privatizačnej komisie. Pri osobách v uvedenom postavení nie je vylúčené okrem postihu podl’a predmetnej kvalifikovanej skutkovej podstaty naplnenie znakov skutkovej podstaty trestného činu porušovania povinností pri správe cudzieho majetku podl’a \237 slovenského TZ ${ }^{60}$, resp. \220 českého TZ.

Česká právna úprava obsahuje v tomto výpočte prvej kvalifikovanej skutkovej podstaty ( $\int 256$ ods. 2 českého TZ s trestnou sadzbou dva roky až osem rokov) aj postavenie páchatel'a ako člena organizovanej skupiny, čo slovenské ustanovenie zarad'uje až do najprísnejšej kvalifikovanej skutkovej podstaty [S 266 ods. 3 písm. b) slovenského TZ, člen nebezpečného zoskupenia] s podstatne vyššou trestnou sadzbou (sedem rokov až dvanást' rokov).

V oboch právnych úpravách sa ako okolnost’ podmieňujúca použitie vyššej trestnej sadzby posudzuje aj korupčný prvok - teda inak znaky trestných činov korupcie: žiadanie, prijatie alebo prijatie sl'ubu majetkového alebo iného prospechu. Z tohto dôvodu je tak rovnako ako podl’a českej právnej úpravy, tak aj podl’a slovenskej právnej úpravy vylúčený jednočinný súbeh s prijímaním úplatku. Zákonodarca by mal v prípade českého TZ i slovenského TZ zvážit', či by postačoval postih korupčných aktivít podl'a všeobecných skutkových podstát trestných činov korupcie. Postup pri verejnom obstarávaní / zadáni veřejné zákazky je obstarávaním všeobecného záujmu (\$ 331 ods. 1 českého TZ, resp. \329 ods. 1 slovenského TZ). ${ }^{61}$ Tým by sa umožnil jednočinný súbeh s trestnými činmi korupcie, ktoré navyše umožňujú diferencovaný postih podl’a závažnosti, najmä podl'a rozsahu činu v kvalifikovaných skutkových podstatách. ${ }^{62}$

Slovenská právna úprava, na rozdiel od českejprávnejúpravy ako kvalifikačné znaky ustanovuje aj osobitný motív a závažnejší spôsob konania. Pri predmetnom trestnom čine ako osobitný motív prichádza do úvahy spáchanie činu na objednávku [\$ 140 písm. a) slovenského TZ], resp. ako závažnejší spôsob konania prichádza do úvahy spáchanie činu porušením dôležitej povinnosti vyplývajúcej z páchatel’ovho zamestnania alebo uloženej mu podl’a zákona [؟ 138 písm. h) slovenského TZ], spáchanie činu organizovanou skupinou [písm. i)] - adekvátne

60 Rozsudok Najvyššieho súdu SR zo dňa 15. 11. 2018, sp. zn. 5 To 2/2018, s. 68-69.

$61 \mathrm{~K}$ širokému výkladu tohto pojmu pozri BELEŠ, Andrej. Korupcia v súvislosti s obstarávaním veci všeobecného záujmu. Justičná revue, 2017, č. 8-9, s. 1009-1020.

62 Pri slovenskej právnej úprave je okrem toho nekoncepčne ustanovená nižšia trestná sadzba pri \266 ods. 2 TZ (dva roky až osem rokov) ako pri prijímaní úplatku (v súvislosti s obstarávaním veci všeobecného záujmu) v základnej skutkovej podstate podl’a \ 329 ods. 1 TZ (tri roky až osem rokov). 
ako podl’a \ 256 ods. 2 písm. a) českého TZ ${ }^{63}$; menej pravdepodobné je použitie verbálneho násilia na spáchanie činu [písm. d)], príp. využitie podriadenosti [písm. g)].

Ak ide o spáchanie činu nie organizovanou skupinou ${ }^{64}$, ale zločineckou skupinou ${ }^{65}$, ide o kvalifikáciu podl'a najprísnejšej kvalifikovanej skutkovej podstaty trestného činu (\$266 ods. 3 slovenského TZ). Spáchanie činu organizovanou zločineckou skupinou (\$ 129 českého TZ) český kódex ako okolnost’ podmieňujúcu použitie vyššej trestnej sadzby neustanovuje. V prípadoch, akým bol tzv. nástenkový tender so zapojením ministrov - členov vlády ako páchatel'ov zločinu je potrebné osobitne skúmat' možnú existenciu zločineckej skupiny, pretože „obchod“ v uvedenom objeme 97,6 milióna eur je náročné spáchat' na „vlastnú päst“", bez d’alšieho politického krytia, resp. možnosti úspešne legalizovat' výnos z trestnej činnosti. Aj Najvyšší súd SR uviedol, že išlo o systematickú činnost' smerujúcu $\mathrm{k}$ fingovaniu verejného obstarávania, pričom vo svojich funkciách sa nachádzali na základe politických nominácií: „Tak obžalovaný Ing. A.B., ako aj obžalovaný Ing. PhDr. C.D. boli do svojich funkecii instalovani na návrh vtedajsieho predsedu Slovenskej národnej strany (d’alej len ,SNS'), Ing. J.S. (vid’ výpoved' obžalovaného Ing. A.B.; [...])."V súvislosti s týmto prípadom bola v samostatnom konaní podl’a \266 ods. 1, ods. 2 písm. c), ods. 3 písm. a) slovenského TZ odsúdená osoba, ktorá poskytovala odborné poradenstvo a udelila súhlas na použitie svojho mena ako odborne spôsobilej osoby. Odsúdená považovala za „diskriminačné“, že bola uznaná vinnou ako „neskorší článok“ ret’aze, avšak ,skoršie články“, ktoré s odsúdenými exministrami pripravovali podklady, a najmä osoby, ktoré z verejného obstarávania profitovali, neboli ani trestne stíhané, ani odsúdené. Najvyšší súd SR potvrdil, že obžalovaná bola uznaná vinnou v tomto zmysle skutočne „diskriminačne“, avšak poukázal na zásadu nemo iudex sine actore. ${ }^{66}$

63 „Organizovanou skupinou se rozumi sdruženi více osob, v němžje provedena určitá dèlba úkolì mezi jednotlivé členy

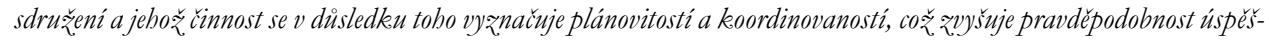
nébo provedeni trestného činu, čimžjsou umocnèny jeho škodlivé dopady pro společnost. Skupina nemusi mít trvalejši charakter a tímto zpuisobem lze spáchat i jen ojedinélý, jednorázový trestný čin. "ŠÁMAL, Pavel. \ 152. In: ŠÁMAL, Pavel a kol. Trestní qákoník. 2. vyd. Praha: C. H. Beck, 2012, s. 1601-1607.

64 Podl'a $\ 129$ ods. 2 slovenského TZ je organizovanou skupinou ,spolčenie najmenej troch osôb na účel spáchania trestného činu, s určitou del'bou určených úloh medži jednotlivými členmi skupiny, ketorej činnost' sa v dôsledku toho vyznačuje plánovitostou a koordinovanostou, čo zvyšruje pravdepodobnost'úspešného spáchania trestného činu."

65 Zločineckou skupinou sa podl’a $\int 129$ ods. 4 slovenského TZ rozumie „štruktúrovaná skupina najmenej troch osôb, ketorá existuje počas určitébo časovébo obdobia a koná koordinovane s cielom spáchat'jeden alebo viacej zločinov, trestný čin legalizácie výnosu z trestnej činnosti podl'a $\int 233$ alebo niektorý z trestných činov korupcie podl'a ôsmej blavy tretiebo dielu osobitnej časti na účely priamebo alebo nepriameho získania finančnej alebo inej výhody."

66 „V tomto smere treba dat' za pravdu obhajobe, že obžalovaná N. W. bola odsúdená ,diskriminačne; túto ,diskrimináciu' ale nespôsobili súdy, ktoré roz̧hodujú len o tých veciach, $v$ ktorých im bola podaná obžaloba, ale orgány činné v trestnom konaní, ktoré napriek relevantným podozreniam voči takýmto osobám neviedli vyšstrovanie dostatočne razantne tak, aby im trestnú ćinnost' preukázali (napr. sa neuskutočnili prebliadky iných priestorov a pozemkov na MVaRR SR [Pozn. - Ministerstvo výstavby a regionálneho rozvoja SR], ÚVO, u členov vit’azného konzorcia, domové prebliadky u podozrivých osôb; nebolo vykonané sledovanie osôb, resp. použité informačno-technické prostriedky atd.)."Rozsudok Najvyššieho súdu SR zo dňa 21. 11. 2019, sp. zn. 5 To 6/2019, s. 16. 
Kvalifikácia podl'a najprísnejšej skutkovej podstaty trestného činu sa - podl’a slovenského TZ - uplatní aj v prípade, ak je činom spôsobená škoda vel'kého rozsahu, teda najmenej $133000 €$. Z hl'adiska tohto znaku je slovenský TZ podstatne prísnejší ako český TZ, pretože ak je spáchaná škoda rádovo v miliónoch eur (bez naplnenia iných kvalifikačných znakov), zakladá to dôvod na aplikáciu \266 ods. 3 slovenského TZ so sadzbou sedem až dvanást' rokov, zatial’čo česká právna úprava stanovuje len kvalifikačný znak spôsobenia značnej škody alebo získania značného prospechu podl’a \ 256 ods. 2 písm. b) a c) českého TZ s trestnou sadzbou dva roky až osem rokov. Aj v uvádzanom prípade tzv. nástenkového tendra boli exministri výstavby odsúdení na úhrnné tresty odňatia slobody 11 rokov, resp. 9 rokov, avšak pre úplnost' je potrebné dodat', že skutky boli u prvého z nich kvalifikované ako jednočinný súbeh zločinu machinácií pri verejnom obstarávaní a verejnej dražbe spolupáchatel'stvom podl’a \20, \266 ods. 1, ods. 2 písm. c), ods. 3 písm. a) slovenského TZ a obzvlášt’ závažného zločinu zneužívania právomoci verejného činitel'a podl'a \326 ods. 1 písm. a), ods. 4 písm. b) slovenského TZ. ${ }^{67}$ Z hl'adiska naplnenia kvalifikačného znaku spôsobenia škody vel'kého rozsahu (ods. 3), resp. značná škoda (ods. 2) vznikla v podmienkach SR polemika, či za spôsobenú škodu je potrebné považovat' celú hodnotu zákazky alebo len tú čast' hodnoty, ktorá je ujmou iného subjektu, teda by predstavovala zisk následkom splnenia zákazky, keby verejné obstarávanie nebolo manipulované. V takom prípade je podiel zisku potrebné určit' znaleckým dokazovaním. Prvý názorový prúd vychádza z toho, že chráneným objektom je záujem na riadnom a zákonnom priebehu verejného obstarávania, a teda zákonné ustanovenie má zabránit' tomu, aby sút'ažitelia machináciami nezískali zákazku ako takú, nie len čistý zisk. Z pohl’adu druhého názorového prúdu je to irelevantné, pretože zákon vyžaduje preukázanie spôsobenej škody, ktorej výška nezodpovedá celej zákazke. ${ }^{68}$

Najvyšší súd SR sa už dlhší čas prikláňa k druhému názorovému prúdu. ${ }^{69}$ Predmetným trestným činom sa totiž trestá dojednanie prednosti alebo výhodnejších podmienok na úkor iných sút'ažitel’ov, preto poškodeným subjektom nie je verejný obstarávatel', ale iní, potenciálni sút'ažitelia alebo účastníci, a to platí aj v prípade prvej alternatívy objektívnej stránky. Súd v prípade tzv. nástenkového tendra k tomu uviedol: „Pre vyčíslenie takto spôsobenej škody bude potrebné ustálit', aký zisk by neúspešný sút’ažitel' / uchádzač mohol dosiahnut' nebyt' trestnej činnosti páchatel'a. I ked' zákon výslovne použiva termín ,ujma na zisku', najvyšši súd kvôli doterajšej nejednotnej roz̧odovacej praxi konštatuje, že pri jej

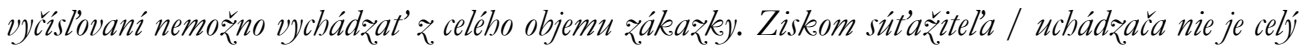
objem zákazky, bez obladu na to, aké by mal sútažitel' / uchádzač v súvislosti s verejným obstarávanim / dražbou náklady. Zisku je treba rozumiet' (zjednodušene) ako rozdielu medzi výnosmi

67 Rozsudok Najvyššieho súdu SR zo dňa 15. 11. 2018, sp. zn. 5 To 2/2018.

68 Bližšie ŠANTA, Ján. Machinácie pri verejnom obstarávanipodla Trestnébo zákona Slovenskej republiky. Dostupné z: https://www.ja-sr.sk/files/Machinacie_JUDr_Santa.pdf [cit. 1. 12. 2020].

69 Uznesenie Najvyššieho súdu SR zo dňa 6. 11. 2013, sp. zn. 1Tost 21/2013. 
a nákladmi súvisiacimi s realizáciou predmetu zákazky [... " ${ }^{\text {"70 }}$. Navrhovaná legislatívna zmena podla Pripomienky ÚVO počíta s nahradením pojmu škoda ako kvalifikačného znaku pojmom rozsah. Pojem rozsah by mal byt' špeciálne pre trestný čin definovaný v $\int 125$ ods. 1 slovenského TZ ako ,zmluvná cena dojednaná qadaním qákaqky alebo koncesie; ak táto zmluvná cena nebola dojednaná, rozsahom činu sa rozumie predpokladaná hodnota zákazky, koncesie alebo sútaže návrhov. Akpredpokladaná hodnota zákazky, koncesie alebo sútaže návrhov nie je stanovená alebo je zjavne podhodnotená alebo nadhodnotená, urči sa na základe znaleckého posudku alebo odborného vyjadrenia."To by v porovnaní s uvedeným výkladom Najvyššieho súdu predstavovalo sprísnenie trestnej represie, pretože páchatelovi by sa ako kvalifikačný znak na t’archu pripísala celá (dojednaná alebo predpokladaná), hodnota zákazky, nie len rozdiel medzi výnosmi a nákladmi súvisiacimi s realizáciou. Návrh sa tak prikláňa k výkladu podl’a prvého názorového prúdu uvedeného vyššie.

V porovnaní s tým, je situácia $v$ zmysle českého TZ jednoduchšia: na naplnenie kvalifikovanej skutkovej podstaty nie je nevyhnutné preukázanie spôsobenia značnej škody [S 256 ods. 2 písm. b)], pretože postačuje preukázanie získania značného prospechu pre seba alebo pre iného [ 256 ods. 2 písm. b) českého TZ], čo predstavuje 1000000 Kč (cca $38000 €$ ). Tým sa česká právna úprava približuje výkladu podla Najvyššieho súdu SR a je voči páchatel'ovi benevolentnejšia ako návrh podl’a Pripomienky ÚVO. Prospech je možné vypočítat' ako možný zisk z realizovanej zákazky, avšak do prospechu je možné započítat' aj imateriálny prospech zo získania zákazky - teda získanie prostriedkov na chod spoločnosti, vylepšenie renomé jej úspešnou realizáciou a pod. Pre naplnenie kvalifikačného znaku potom postačuje len orientačný výpočet materiálneho prospechu. ${ }^{71}$ Takýto postup v podmienkach slovenského TZ nie je možný, pretože

70 Rozsudok Najvyššieho súdu SR zo dňa 15. 11. 2018, sp. zn. 5 To 2/2018, s. 66-67: „Z týchto úvah potom

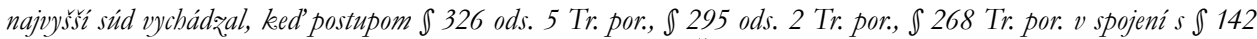
a nasl. Tr. por. doplnil dokazovanie o výsluch znalkyne - Ing. M.Š. PhD., aby zistil, že minimálna hodnota čistého zisku iného potencionálneho sút'ažitel’a by v prípade riešeného verejného obstarávania nemohla byt' nižšia ako 3.563.795€."

71 Uznesenie Nejvyššího soudu ČR zo dňa 30. 6. 2020, sp. zn. 5 Tdo 1559/2018, body 92 a 93: „Imateriální prospěch spatroval krajský soud v možnosti vỉbec realizovat zakázku, nebot'v takových prípadech má obchodni společnost jako vitězný dodavatel práci pro své zaměstnance a na svi̊j ,provoz' tak quiská prostředky, byt’ by pouze pokryla vlastni náklady, jež by bezjiného využiti svých zdroju musela beztak vynaložit. Dalšim pozitivem, výhodou, tedy prospěchem, který samotné quiskání zakázky prináš́, je zvýšení obratu obchodni společnosti, který často bývá v praxi jedním

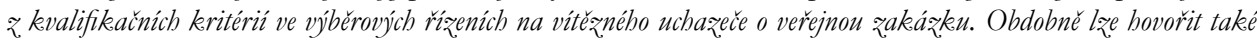
o snazším prokazováním technické zpưsobilosti [...], pro prípadnou daľ̌i účast v zadávacích ř́żeních. Možnost realizovat veřjné zakázky nezrúdka znamená pro dodavatele také profit ve formě další reference zvyšující její kredit na obchodním trhu, v prípadé úspěsné realizace si dodavatel vylepšuje renomé apod. [...] Ovšem prí pobledu na konkéétni finančni objemy, za něž byly vysoutěęeny veřejné zakázky [...], je zcela zjevné, že pro naplnèni znaku značnébo

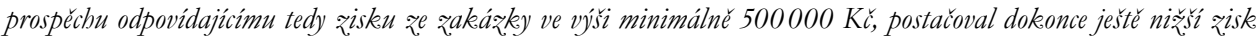
odvozený procentem z hodnoty predmètu jednotlivých zakázek. Nejnižši hodnota verejné zakázky, k.teré jsou predmè-

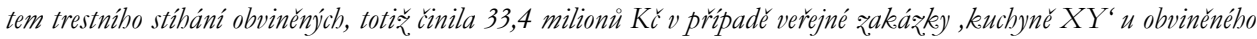
D. H. a s uvažovaným minimálnim ziskem ve výsi $500000 \mathrm{~K} \check{c}$ by to znamenalo pouze 1,5\% zisk pro dodavatele. 
je nereálne do výpočtu vzniknutej škody započítavat' aj potenciálny ušlý imateriálny prospech neúspešných konkurentov.

\subsection{Ustanovenia \267 a 268 slovenského TZ a \257 českého TZ}

Taktiež ustanovenia \267 a 268 slovenského TZ trestného činu machinácií pri verejnom obstarávaní a verejnej dražbe obsahujú adekvátne znaky ako trestný čin pletichy prí zadání verejné zakááky a prí veŕejné soutěži podl'a \257 českého TZ - s určitými výnimkami.

Spoločnými prvkami sú:

a) Postih konania, ktorým páchatel prinúti iného, aby sa zdržal účasti na verejnom obstarávaní / v zadávacím rízeni alebo ve verejné soutěži, a to závažnejším spôsobom konania $^{72}$ (slovenský TZ), alebo lstí nebo pobrǐ̌̌kou násili nebo jiné téžké újmy (český TZ), čo je však málo pravdepodobné, pretože ekonomická kriminalita sa pácha najmä ako kriminalita bielych golierov, čiže „džentlmenská“ kriminalita, pri ktorej sa verbálne alebo fyzické násilie používa až ako prostriedok ultima ratio; predmetné ustanovenie je rezíduom zo začiatku 90 -tych rokov, ked’ ekonomická kriminalita organizovaného charakteru sa prejavovala aj primitívnejšími násilnými formami, ako uvádzala aj dôvodová správa k zákonu č. 557/1991 Zb.: „,...] kede návrh vycházel z.poznatkì o narušováni rovnosti podminek veřejné soutěžé, kdy je privatizace provádèna touto formou, o narušováni podminek dražby, kdy v rámci malé privatizace docházi k nátlaku na účastniky dražby, ke vyhrožováni nebo zastrašování, popr. ke nabidkám úplatkiu, byl návrh Výboru pro lidská práva akeceptován. "73 Uvedené ustanovenie v slovenskej a českej právnej úprave je teda možné kriticky skúmat', či je obsolentné a efektívnejšia by bola jeho redukcia len na kvalifikačný znak: spáchanie činu závažnejším spôsobom konania v slovenskom právnom prostredí. Alebo by v českom TZ aj slovenskom TZ zákonodarca pristúpil k úplnému vypusteniu uvedeného ustanovenia a potenciálne by sa takéto prípady mohli kvalifikovat' ako súbeh s trestným činom vydierania.

b) Postih korupčného konania - aktívnej i pasívnej korupcie, ktorá súvisí so zdržaním sa účasti vo verejnom obstarávaní / v zadávacím ř́zeni alebo ve veŕejné soutěž $i$ - skutková podstata trestného činu je naplnená bez ohl'adu na to, či osoba, ktorá prijme

$\cdots$

Ostatni verejné zakázky, na jejich žprotiprávnim ovlivnèni se obvinènípodileli, nebo k takovému jednáni poskytli pomoc, dosahovaly vyššcich hodnot. Z procentuálního hlediska vyjadrujicíbo pomèr meżi celkovou cenou zakáaky a částkou 500000 Kč jako spodni branici značného prospèchu by se tedy jednalo o ještě nižši finančni príjem. Nejuyšsimu soudu se nejeví jako reálné, aby uchazeč o veřejnou zakázku kalkuloval prri stanovení cenové nabídky s méně jak 2\% ziskem, a to mimo jiné i s obledem na ţv. vedlejší výdaje (odmèny spř́żnèným osobám), jež byly spojeny s manipulovanými zadávacimi ř́zenimi. "[Pozn.: vyznačil autor]. Výpočet značného prospechu vo výške 500000 Kč sa viaže na právny stav podl'a \138 českého TZ pred úćinnost’ou novelizácie zákonom č. 333/2020 Sb., následkom čoho boli jednotlivé výšky úrovní škôd ako kvalifikačných pojmov zdvojnásobené.

72 Podl’a \ 138 slovenského TZ, najmä písm. d), f), g): násilím, hrozbou bezprostredného násilia alebo hrozbou inej t’ažkej ujmy, l'st'ou, príp. využitím neskúsenosti.

73 Dôvodová správa k zákonu č. 557/1991 Zb. Dostupné z: https://www.psp.cz/eknih/1990fs/tisky/ t1002_01.htm [cit. 25.11.2020]. 
majetkový prospech za to, že sa zdrží účasti, skutočne disponuje potrebnými predpokladmi, teda ide o predčasne dokonaný trestný čin ${ }^{74}$. V slovenskej i českej právnej úprave ide o špeciálnu úpravu trestnoprávneho postihu korupcie voči všeobecným ustanoveniam trestných činov korupcie. Napriek tomu, že ide o špeciálne ustanovenia a je daný vyšší spoločenský záujem práve na ochrane verejného obstarávania pred korupčnými aktivitami, táto špeciálna právna úprava v zmysle slovenského TZ i českého TZ určuje - paradoxne - nižšie trestné sadzby v porovnaní so všeobecnými ustanoveniami korupčných deliktov, resp. nediferencuje vyššiu spoločenskú závažnost' podplácania ako prijímania úplatku. ${ }^{75}$ Preto zostáva pre zákonodarcu na uváženie zvýšenie trestných sadzieb pri špeciálnych ustanoveniach, zníženie trestných sadzieb pri všeobecných ustanoveniach, príp. diferenciácia trestných sadzieb pri formách pasívnej korupcie (s vyššou závažnost'ou) a aktívnej korupcie ${ }^{76}$.

Medzi rozdielne prvky právnych úprav patrí:

a) skutočnost', že ochrana podl'a \257 českého TZ - na rozdiel od slovenskej právnej úpravy - sa netýka verejnej dražby,

b) slovenská práva úprava neobsahuje kvalifikované skutkové podstaty, čiže nerozlišuje závažnost' trestného činu napr. podl'a rozsahu, v ktorom bol alebo podl'a úmyslu páchatel'a mal byt' trestný čin spáchaný - na rozdiel od toho \257 ods. 2 a 3 českého TZ ustanovujú ako kvalifikačný znak motív získat' pre seba alebo pre iného značný prospech alebo prospech vel'kého rozsahu: napr. konatel' obchodnej spoločnosti ponúkne inému majetkový prospech za to, že sa zdrží účasti na verejnom

74 Uznesenie Nejvyššího soudu ČR zo dňa 29. 4. 2020, sp. zn. 5 Tdo 319/2020, bod 37: „Byt’ by se později ukázalo, že by ovlivnovaný uchažeč o veréjnou zakázken byl se svou nabidkou stejnè neíspěšny či by dokonce jeho nabidka byla vyrazena z formálnich divvodů pro nesplnèní zákonných požadavkư nebo požadavkư zadavatele, presto by bylo možno dopustit se trestnébo činu pletich prí zadáni veřejné zakázky a pri verejné soutě̌̌i, a to i dokonanébo.

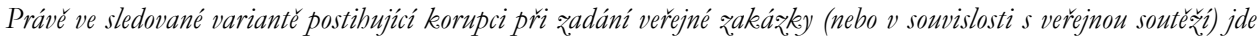

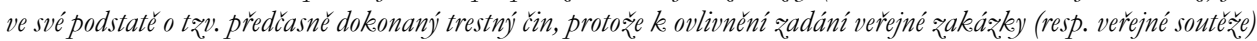
vỉbec nemusi dojit, dokonce se ani ne⿻̌ádá, aby tžv. aktivním üplatkárstvím pachatel primél jinébo (ovlivñovanébo

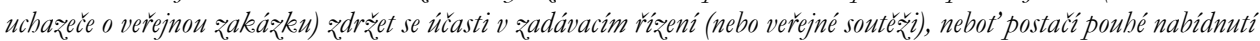
č slíbeni úplatku se zámèrem primèt jinébo żdrěet se takové úcasti, aniž by bylo treba, aby taková nabidka či slib byly drubou stranou akceptovány."

75 Trestná sadzba pri $₫ 267$ a 268 slovenského TZ je podstatne nižšia (jeden rok až pät’ rokov) ako pri prijímaní úplatku podl’a $₫ 328$ ods. 1 TZ (dva roky až pät’ rokov) a najmä $₫ 329$ ods. 1 TZ (tri roky až osem rokov), resp. pri podplácaní, avšak až v kvalifikovanej skutkovej podstate ( $\$ 333$ ods. 2 TZ: dva roky až pät' rokov, $\ 333$ ods. 3 TZ: pät' až dvanást' rokov). Taktiež trestná sadzba podl’a $\ 257$ ods. 1 českého TZ (až na tri roky) je nižšia ako trestná sadzba pri trestnom čine přijetí úplatku podl’a $\ 331$ ods. 1 českého TZ (až na štyri roky), resp. \331 ods. 2 českého TZ (šest' mesiacov až pät’ rokov), resp. pri trestnom čine podplácení, avšak až v kvalifikovanej skutkovej podstate podl’a $\$ 332$ ods. 2 českého TZ (jeden rok až šest' rokov).

76 V prípade úvahy o vypustení týchto špeciálnych ustanovení postihujúcich korupciu by bolo potrebné zvážit', či tieto konania, ako je zdržanie sa účasti vo verejnom obstarávaní) je možné subsumovat' pod všeobecné skutkové podstaty trestných činov korupcie, najmä pod pojem obstarávanie veci všeobecného záujmu. Prikláňame sa k názoru, že takáto právna kvalifikácia by nebola možná. 
obstarávaní ( $v$ zadávacím rį́enî), aby získal pre svoju právnickú osobu (teda pre iného) značný prospech ${ }^{77}$;

c) slovenská právna úprava neobsahuje trestnoprávny postih protizákonných dohôd medzi účastníkmi verejného obstarávania / zadáni veřejné zákazky a konania smerujúceho k získaniu zákazky za neprimerane vysokú alebo inak nevýhodnú cenu na rozdiel od $\int 257$ ods. 1 písm. d) českého TZ.

$\mathrm{V}$ tomto poslednom bode sa česká právna úprava približuje trestnoprávnemu postihu konaní súvisiacich s verejným obstarávaním v Rakúsku a Nemecku. Rakúsky trestný zákonník $\mathrm{StGB}^{78}$ totiž obsahuje trestný čin dohôd obmedzujúcich sút'až pri verejnom obstarávaní (Wettbewerbsbeschränkende Absprachen bei Vergabeverfahren) podl'a \168b rakúskeho StGB. Tento trestný čin postihuje podanie žiadosti o účast' na verejnom obstarávaní, zloženie ponuky alebo vedenie rokovaní, ak takéto konanie spočíva na protiprávnej dohode, ktorej účelom je pohnút' obstarávatel'a / zadávatel'a k prijatiu určitej ponuky. ${ }^{79}$ Podnikatelia sa dohodnú, kto si bude účtovat' kol'ko za dodávané tovary, resp. poskytované služby. Účelom dohody je najmä určit' obsah ponúk. Z dohody je zvyčajne jasné, kto dostane objednávku ako „najlepší uchádzač“‘. 80

Podobne aj nemecký trestný zákonník StGB ${ }^{81}$ taktiež ustanovuje trestný čin dohôd obmedzujúcich sút'až pri verejnom obstarávaní (Wettbewerbsbeschränkende Absprachen bei Ausschreibungen) podl'a \ 298 nemeckého StGB - len s jediným rozdielom, že v objektívnej stránke skutkovej podstaty je ako konanie stanovené len odovzdanie ponuky, ktorá spočíva na protiprávnej dohode. V rakúskej a nemeckej právnej úprave sa priamo osobitne verejného obstarávania týka len tento trestný čin ( $\int 168$ b rakúskeho StGB, resp. \298 nemeckého StGB). Rakúsky ani nemecký trestný zákon teda nekriminalizujú machinácie pri verejnom obstarávaní v takom zmysle a tak rozsiahlo ako slovenská a česká právna úprava. Ak by prišlo ku korupčným aktivitám v súvislosti s verejným obstarávaním, tieto je možné postihnút' všeobecnými skutkovými podstatami trestných činov korupcie. Bližší rozbor predmetných úprav však presahuje zameranie predkladanej štúdie.

77 Uznesenie Nejvyššího soudu ČR zo dňa 29. 4. 2020, sp. zn. 5 Tdo 319/2020, bod 36.

78 Bundesgesetz vom 23. Jänner 1974 über die mit gerichtlicher Strafe bedrohten Handlungen (Strafgesetzbuch - StGB) StF: BGBl. Nr. 60/1974 (NR: GP XIII RV 30 AB 959 S. 84. BR: S. 326. NR: Einspr. d. BR: Einspr. d. BR: 1000 AB 1011 S. 98.), ostatne v znení zákona BGBl. I Nr. 111/2019 (NR: GP XXVII RV 1 AB 14 S. 6. BR: AB 10276 S. 899.) [CELEX-Nr.: 32017L1371].

79 Ust. $\int 168$ b ods. 1 rakúskeho StGB. Ust. ods. 2 voči uvedenej základnej skutkovej podstate trestného činu obsahuje osobitný dôvod zániku trestnosti činu.

80 BERTEL, Christian a Klaus SCHWEIGHOFER. Österreichisches Strafrecht. Besonderer Teil I. $\int 75$ bis 168 e StGB. Wien: Springer-Verlag, 2010, s. 334.

81 Strafgesetzbuch in der Fassung der Bekanntmachung vom 13. November 1998 (BGBl. I S. 3322), das zuletzt durch Artikel 1 des Gesetzes vom 9. Oktober 2020 (BGBl. I S. 2075) geändert worden ist. 


\section{Záver}

Forma a obsah trestnoprávneho postihu protiprávnych konaní v súvislosti s verejným obstarávaním / zadáním veřejné zákazky zostali v slovenskej aj českej právnej úprave v zásade verné právnej úprave v zmysle TZ 1961 prijatej na federálnej úrovni začiatkom 90-tych rokov. Konvergentné prvky slovenskej a českej právnej úpravy posilňuje aj transpozícia štandardov verejného obstarávania z práva EÚ.

Napriek tomu je možné identifikovat' niekol'ko divergentných atribútov. Trestný čin machinácií pri verejnom obstarávaní a verejnej dražbe v základnej skutkovej podstate podl'a \266 ods. 1 slovenského TZ si v porovnaní s trestným činom podl’a \256 českého TZ zachoval nedostatočne určitú alternatívu objektívnej stránky, ktorou je konanie $\mathrm{v}$ rozpore so všeobecne záväzným právnym predpisom o verejnom obstarávaní. Takúto adekvátnu - tiež nedostatočne určitú skutkovú podstatu trestného činu obsahuje ustanovenie \248 ods. 2 druhá alinea českého TZ. V súlade so zásadou subsidiarity trestnej represie je možné túto alternatívu objektívnej stránky naplnit’ len tými najzávažnejšími porušeniami zákona o verejnom obstarávaní, ktoré najmä porušujú princípy rovného zaobchádzania, nediskriminácie a transparentnosti vyplývajúce zo smernice o verejnom obstarávaní. Pre českého zákonodarcu zostáva na uváženie, či takéto ustanovenie by malo byt' systematicky priradené k trestným činom podl’a \256 a 257 českého TZ a či by nemalo byt' spresnené tým, aké konkrétne porušenia osobitného zákona sú trestnoprávne relevantné. Požiadavka spresnenia ustanovenia sa týka adekvátne aj prvej aliney \266 ods. 1 slovenského TZ.

Obsah týchto princípov je dostatočne zrejmý z rozhodovacej činnosti Súdneho dvora EÚ a vnútroštátnych súdov (najmä Nejvyš̌š́ho soudu ČR). Tieto princípy majú zabránit' trestnej činnosti, ako je zadanie verejnej zákazky vopred určenému dodávatel'ovi rôznymi spôsobmi vylúčenia skutočnej sút'aže, vrátane imitovania sút'aže pomocou „nastrčených“ spriaznených obchodných spoločností.

Z hladiska rozsahu kriminalizácie je táto v určitých aspektoch v podmienkach slovenského TZ širšia (dve alternatívy objektívnej stránky) a v určitých aspektoch užšia. Pojem verejná sút’až je širším pojmom ako verejné obstarávanie a základná skutková podstata podl'a \266 ods. 1 slovenského TZ tento širší pojem nepoužíva; je uvedený len v kvalifikovanej skutkovej podstate (ods. 2), čo je obsoletné. Zaujímavým rozdielom je fakt, že \256 ods. 1 českého TZ nepredstavuje blanketovú alebo odkazovaciu skutkovú podstatu, čo o ust. \266 slovenského TZ nemožno tvrdit'.

Obe právne úpravy obsahujú navzájom adekvátne znaky kvalifikovaných skutkových podstát. Z hladiska spáchania škody vel'kého rozsahu je slovenský TZ podstatne prísnejší. V prípadoch páchania predmetných trestných činov vysokými štátnymi úradníkmi je potrebné osobitne skúmat' naplnenie znakov spáchania činu organizovanou (zločineckou) skupinou, aby sa zabezpečil postih skutočných organizátorov zmanipulovaného 
obstarávania, resp. recipientov výhod. V opačnom prípade sa trest len pre „neskoršie články“ ret’azca nemusí javit’ ako spravodlivýs ${ }^{82}$. Výpočet značnej škody, resp. škody vel'kého rozsahu je (v podmienkach SR) viazaný na zisk, ktorý by neúspešný sút'ažitel' potenciálne mohol dosiahnut', k čomu je potrebné vykonat' znalecké dokazovanie. Česká právna úprava však obsahuje znak získania značného prospechu, ktorého výpočet nie je natol'ko náročný a je možné do neho zarátat' aj imateriálny prospech. Pripomienka ÚVO navrhuje zmenit' v slovenských podmienkach kvalifikačný znak škoda na kvalifikačný znak rozsah, čo znamená sprísnenie trestnej represie.

Navzájom adekvátnymi trestnými činmi sú ust. \267 a 268 slovenského TZ na jednej strane a ust. \257 ods. 1 českého TZ na strane druhej. Rozhodovacia činnost' k týmto ustanoveniam je však podstatne menej rozsiahla. Zákonodarca by mal zvážit' relevantnost' postihu hrozby násilím [〕 257 ods. 1 písm. a) českého TZ, \ 267 písm. a), \} 2 6 8 písm. a) slovenského TZ] a najmä relevantnost' postihu korupčného konania [\$ 257 ods. 1 písm. b), c) českého TZ, \267 písm. b), c) \ 268 písm. b), c) slovenského TZ] s možnost'ou úpravy trestných sadzieb, aby neboli nižšie ako pri všeobecných ustanoveniach postihujúcich korupciu, resp. aby bola diferencovane prísnejšie postihovaná pasívna korupcia. Zaujímavým rozdielom je, že česká právna úprava trestnoprávne postihuje aj protiprávne dohody medzi záujemcami alebo uchádzačmi s motívom dosiahnutia neprimerane vysokej alebo inak nevýhodnej ceny, čím sa česká právna úprava približuje rakúskej a nemeckej.

82 Spravodlivost' je v tomto význame potrebné chápat' ako primeranost' ujmy spôsobenej páchatelovi za spáchaný trestný čin. Pozri KURILOVSKÁ, Lucia a Stanislav ŠIŠULÁK. Spravodlivý trest. Právny obžor, 2020, roč. 103, č. 4, s. 281-296. 